\title{
TWO NEW SPECIES AND A NEW RECORD OF SPATULAPHORUS (ACARI: PYGMEPHORIDAE) PHORETIC ON SCARAB BEETLES (COLEOPTERA: SCARABAEIDAE) FROM FRENCH GUIANA
}

\author{
Alexander A. Khaustov ${ }^{1 *}$ and Andrey V. Frolov ${ }^{2}$
}

\author{
${ }^{1} \mathrm{X}$-BIO Institute, Tyumen State University, Tyumen, Russia; \\ ${ }^{2}$ Zoological Institute, Russian Academy of Sciences, Saint Petersburg, Russia \\ *corresponding author; e-mail: alex1973khaustov@gmail.com
}

\begin{abstract}
Two new species, Spatulaphorus dignus sp.n. and S. porosus sp.n. (Acari: Pygmephoridae), collected from scarab beetles Oxysternon durantoni and Coprophanaeus jasius, respectively, are described from French Guiana. Spatulaphorus brasiliensis Khaustov and Frolov, collected from the beetle Dichotomius borreus, is recorded from French Guiana for the first time. A key to the world species of the genus Spatulaphorus is also provided.
\end{abstract}

KEY WORDS: Heterostigmata, systematics, morphology, key, phoresy.

DOI: 10.21684/0132-8077-2021-29-2-233-245

\section{INTRODUCTION}

Pygmephoroid mites (Acari: Heterostigmata: Pygmephoroidea) have phoretic relationships with a wide range of scarab beetles (Coleoptera: Scarabaeoidea), mostly with dung beetles of the families Geotrupidae and Scarabaeidae (Khaustov and Frolov 2019). Representatives of at least five genera of the family Pygmephoridae are associated with dung beetles: Geotrupophorus Mahunka, 1970; Pygmephorellus Cross and Moser, 1971; Pseudopygmephorellus Khaustov, 2008; Pediculaster Vitzthum, 1931; and Spatulaphorus Rack, 1993 (Dastych and Rack 1993; Dastych et al. 1997; Khaustov 2005, 2007a, b; Rahiminejad et al. 2011; Khaustov and Trach 2012, 2018; Katlav et al. 2015a, b; Khaustov and Frolov 2017, 2018, 2019; Sobhi et al. 2017). The genus Spatulaphorus includes 14 described species (Khaustov and Frolov 2018), all of which are associated with dung beetles of the genera Copris Geoffroy, Onitis Fabricius, Catharsius Hope, Gymnopleurus Illiger (Scarabaeidae), Geotrupes Latreille and Enoplotrupes Lucas (Geotrupidae) in Europe, Asia, South America and Africa (Khaustov and Trach 2012; Khaustov and Frolov 2017, 2018; Sobhi et al. 2017; Khaustov and Trach 2018). Only one species of Spatulaphorus (S. brasiliensis) has been recorded in the Neotropical region. However, Pygmephorellus imbricatipes Mahunka, 1980, described from specimens in the Berlese collection and collected from Phaneus sp. (Scarabaeidae) in Argentina, may be a member of Spatulaphorus (Khaustov and Trach 2012; Khaustov and Frolov 2017) because of the leg chaetotaxy, illustrated in the original description of this species. Previously, mites of the genus Spatulaphorus have never been recorded from French Guiana.
Recently, we had the opportunity to examine phoretic mites of dung beetles of the tribes Phanaeini and Dichotomiini, collected in French Guiana by Olivier Montreuil (National Museum of Natural History, Paris, France). The specimens of Oxysternon durantoni Arnaud and Coprophanaeus jasius (Olivier) (Pahaneini) bore two new species of Spatulaphorus. On Dichotomius borreus (Olivier) (Dichotomiini), we found $S$. brasiliensis, which has previously been described from Brazil from another species of Dichotomius.

The aim of this paper is to describe two new species of Spatulaphorus and to present a new record of $S$. brasiliensis from French Guiana.

\section{MATERIALS AND METHODS}

The mites were collected from preserved beetles, housed in the private collection of Olivier Montreuil. The mites were recovered from under the elytra of the beetles. The collected mites were preserved in $70-80 \%$ ethanol and later cleared in lactic acid and mounted in Hoyer's medium. Mite morphology was studied using a Carl Zeiss AxioImager A2 compound microscope equipped with phase contrast and DIC illuminations. Photomicrographs were taken with an AxioCam ICc5 (most micrographs) and Hitachi KP-HD20A (Fig. 6) digital cameras.

The terminology of the idiosoma and legs follows Lindquist (1986); the nomenclature of subcapitular setae and the designation of cheliceral setae follow Grandjean (1944, 1947), respectively. The taxonomic system of Pygmephoroidea follows Khaustov $(2004,2008)$. All measurements are given in micrometers $(\mu \mathrm{m})$ for the holotype and five paratypes (in parentheses). For leg chaetotaxy, the number of solenidia is given in parentheses. 


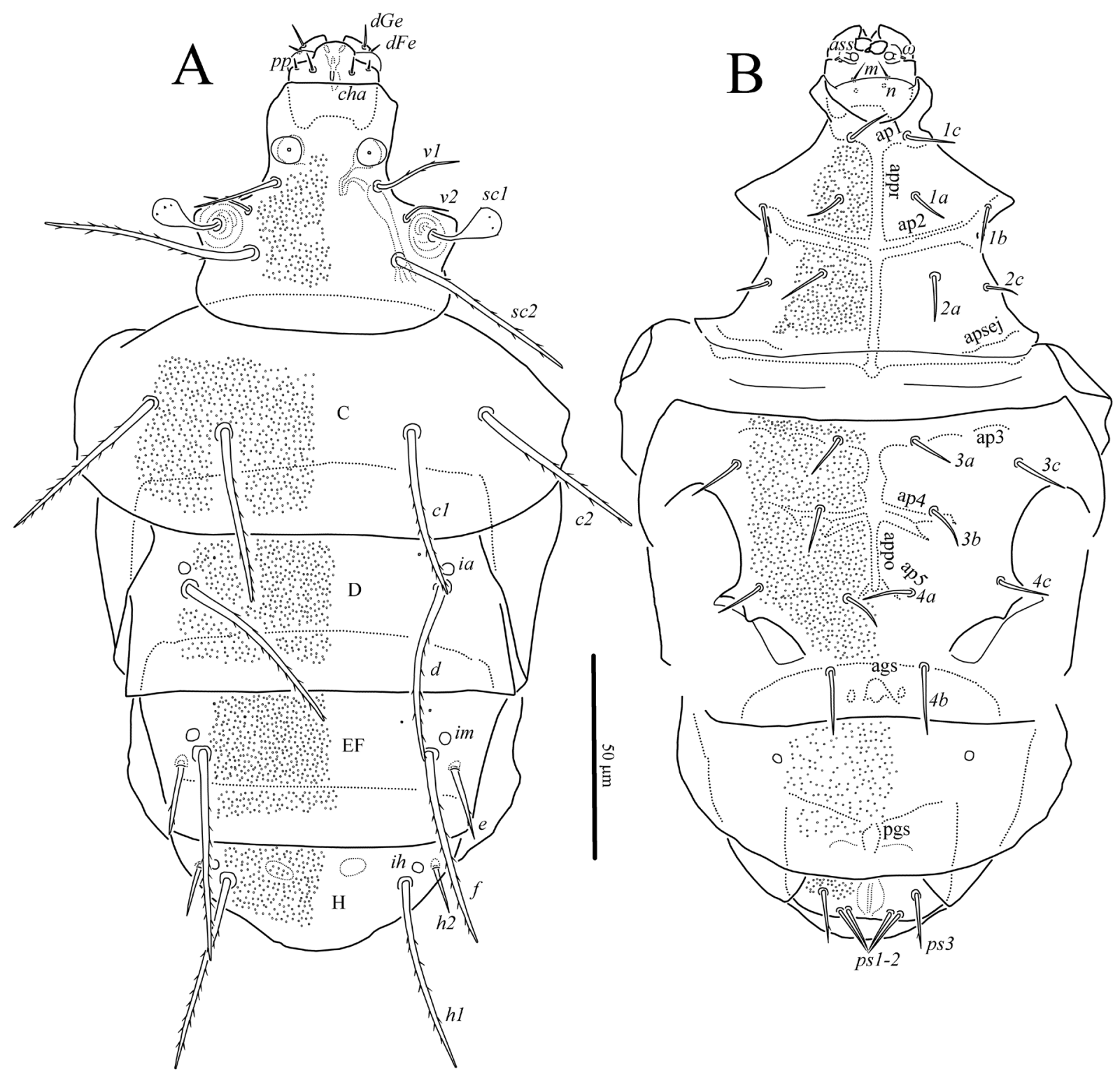

Fig. 1. Spatulaphorus dignus sp.n., female: A-dorsum of body, B-venter of body. Legs omitted.

\section{SYSTEMATICS}

Family Pygmephoridae Cross, 1965

Genus Spatulaphorus Rack, 1993

Type species: Spatulaphorus camerikae Dastych and Rack, 1993, by original designation.

\section{Spatulaphorus dignus sp. $\mathrm{n}$.}

(Figs. 1-6)

Description. Female (Figs. 1-6). Body well sclerotized. Length of idiosoma 210 (205-240), width 120 (120-140).

Gnathosoma (Fig. 6A). Gnathosomal capsule, excluding palps, subrectangular, length 21 (20-23), width 22 (21-23). Dorsum with one pair of needlelike cheliceral setae (cha) 5 (4-5). Dorsal median apodeme present, but poorly developed. Postpalpal setae ( $p p) 2$ (2) spine-like, situated laterad setae $c h a$. Ventral gnathosoma with one pair of smooth, pointed subcapitular setae $m 6(6-7)$ and round pits $n$ situated posteriad $m$. Palps with smooth and weakly blunt-tipped setae $d F e 3$ (3) and $d G e 6$ (6-7) dorsolaterally. Palps ventrally each with mushroom-like accessory setigenous structure (ass) and tiny solenidion. Palps terminated with small blunt-tipped tibial claw and tiny eupathidium-like seta (Fig. 6A). Pharyngeal pump 2 poorly visible, oval with weak transverse striation (Fig. 6B); pharyngeal pumps 1 and 3 not visible.

Idiosomal dorsum (Figs. 1A, 4A, 5A, C, E). All dorsal shields with numerous tiny, barely discernible puncta (Figs. 5A, C, E). Prodorsal shield 


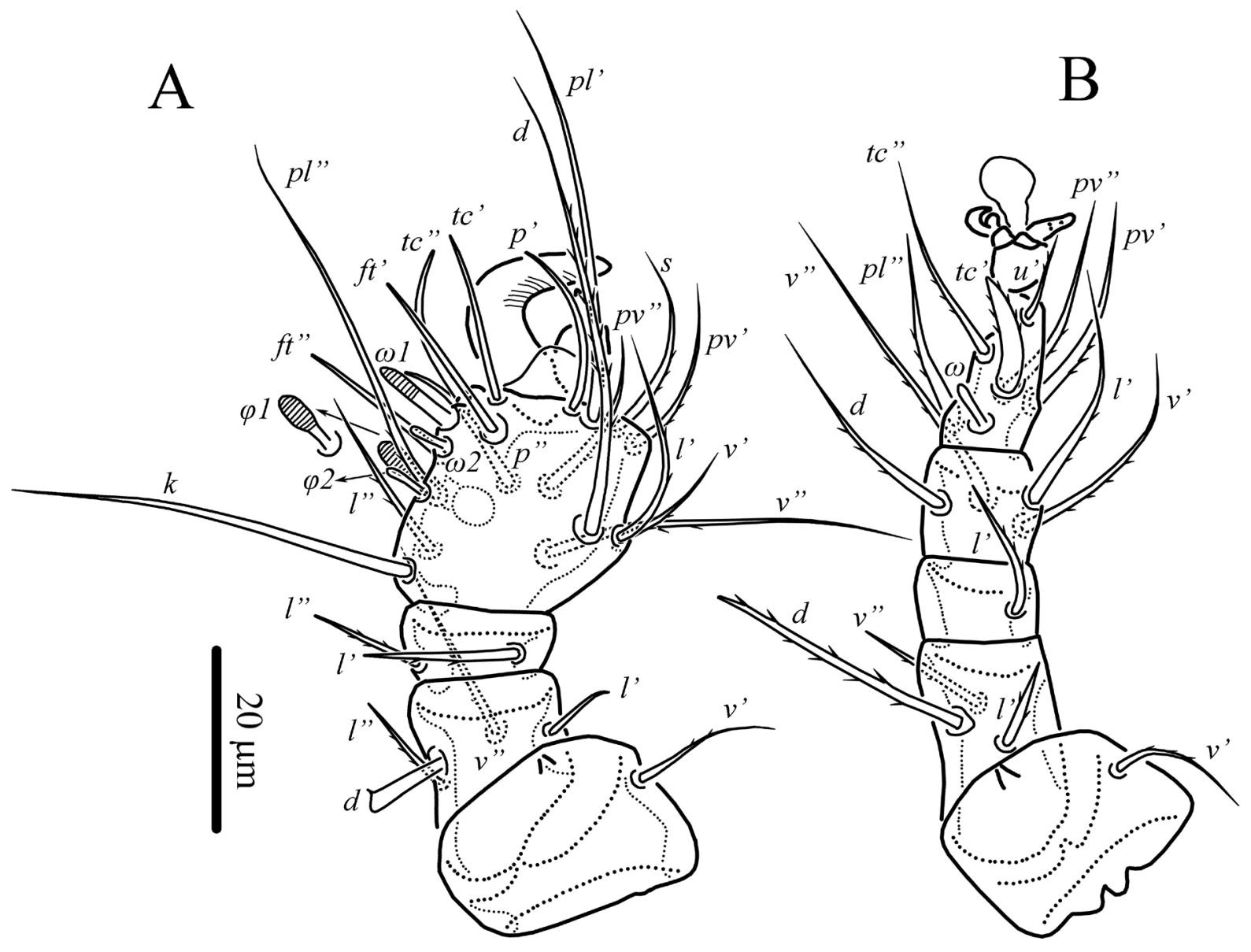

Fig. 2. Spatulaphorus dignus sp.n., female: A-left leg I, dorsal aspect, B-left leg II, dorsal aspect.

with three pairs of setae $(v 1, v 2, s c 2)$, one pair of weakly barbed capitate trichobothria $(s c 1)$ and one pair of round stigmata (Fig. 5A). Stigmata associated with well developed tracheal trunks. All dorsal idiosomal setae blunt-tipped; setae $v 2$ and $h 2$ smooth, other dorsal setae barbed; setae $e$ with one or two barbs. Cupuli ia on tergite D, im on tergite $\mathrm{EF}$ and $i$ on tergite $\mathrm{H}$ large, round. Lengths of dorsal setae: $v 122$ (22-24), v2 11 (11-13), sc2 48 (47-54), c1 41 (39-46), c2 45 (44-48), $d 47$ (4449), e 19 (19-21), f 48 (48-55), h1 47 (45-49), h2 12 (12-13). Distances between setae: $v 1-v 125$ (25-27), v2-v2 38 (38-42), sc2-sc2 36 (36-41), $c 1-c 145$ (45-49), c1-c2 18 (18-22), $d-d 61$ (61-67), e-f 7 (7-8), f-f 55 (55-61), hl-hl 43 (43-47), h1-h2 8 (8-10).

Idiosomal venter (Figs. 1B, 4B, 5B, D, F). All ventral plates with numerous tiny puncta. Setae $1 b$ and $p s 1-2$ pointed; other ventral setae with slightly rounded tips. Setae $1 b$ with a few barbs; setae $p s 3$ usually with one barb, sometimes smooth; other ventral setae smooth. Bases of setae $p s_{3}$ situated distinctly anteriad bases of setae ps 1-2. Apodemes
1 (ap1) and apodemes 2 (ap2) well developed and joined with thick prosternal apodeme (appr); sejugal apodeme (apsej) developed only laterally; apodemes 3 (ap3) weak, not reaching poststernal apodeme (appo); apodemes 4 (ap4) well developed, exceeding beyond bases of setae $3 b$. Apodemes 5 (ap5) well developed, joined with appo and reaching beyond setae $4 a$. Anterior genital sclerite (ags) small, cuplike; posterior genital sclerite (pgs) small, oval, with lateral processes. Posterior margins of posterior sternal plate weakly concave in middle part. Posterior margin of aggenital plate rounded. Lengths of ventral setae: $1 a 9$ (8-11), $1 b 12$ (12-14), lc 12 (12-17), 2a 12 (12-14), 2c 8 (8-9), 3a 11 (13-14), $3 b 11$ (11-13), 3c 14 (14-15), 4a 10 (10-13), $4 b 18$ (18-19), 4c 13 (13-15), ps1 11 (11-13), ps2 12 (12-13), ps3 13 (13-15).

Legs (Figs. 2, 3, 6C). Leg I (Figs. 2A, 6C) slightly thicker than leg II. Setal formula: 1-4-217(4). Tibiotarsus enlarged, with large claw. Setae (u) consolidated into a horn-like structure opposing to claw (Fig. 6C). Tarsal claw blunt-tipped. Seta $d$ of femur spatulate, with short subterminal projec- 


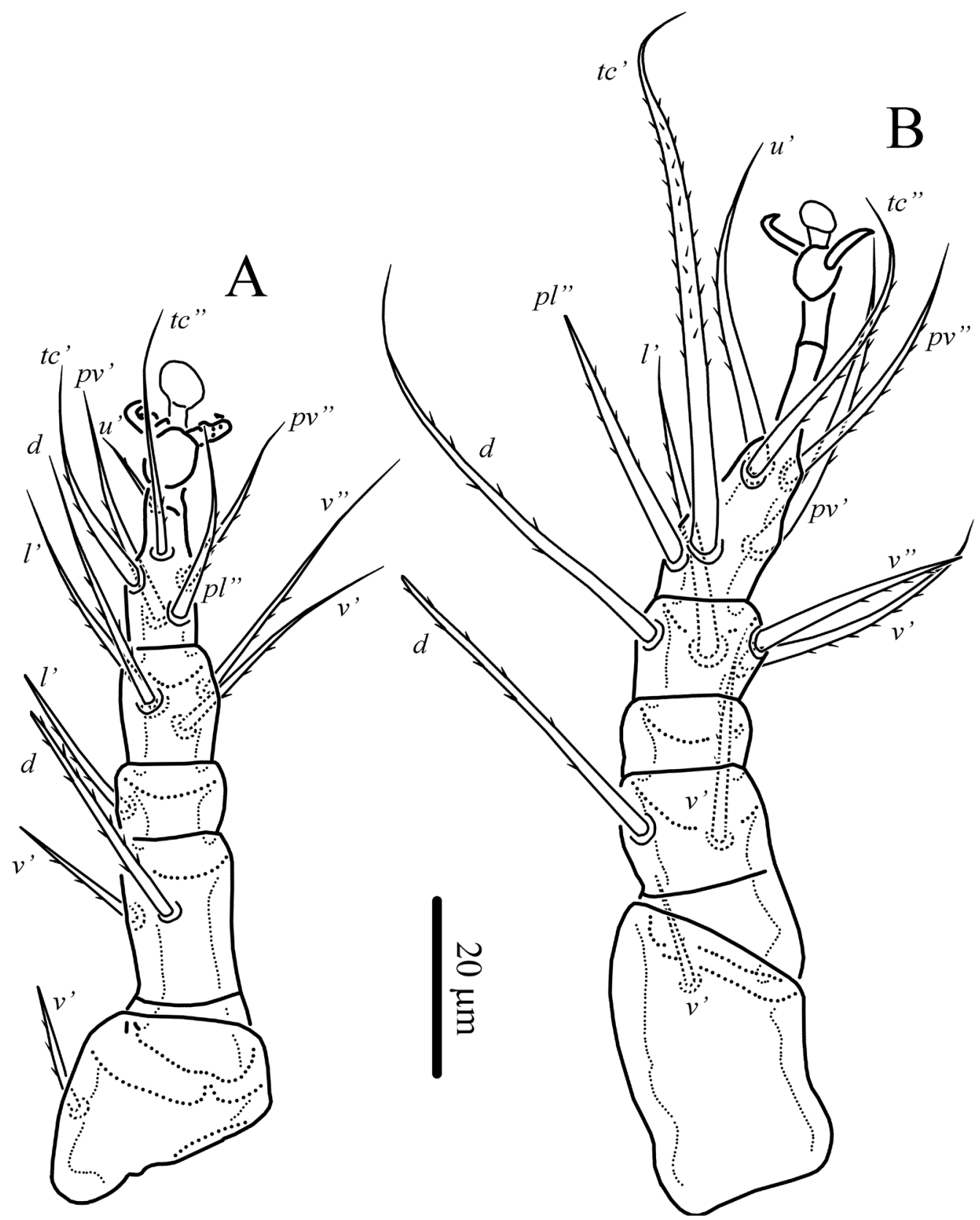

Fig. 3. Spatulaphorus dignus sp.n., female: A—right leg III, dorsal aspect, B — right leg IV, dorsal aspect.

tion. Setae $l$ ' of femur and $k$ of tibiotarsus smooth; other leg setae (except eupathidia $p^{\prime}, p$ ', $t c^{\prime}, t c^{\prime}$, $\left.f t^{\prime}, f t^{\prime \prime}\right)$ sparsely barbed. Setae $l$,,$l$ "' of femur and ( $l$ ) of genu blunt-ended; other leg setae (except eupathidia) pointed. Lengths of solenidia $\omega 110$ (10), $\omega 24$ (4-5), $\varphi 17$ (7-8), $\varphi 25$ (5); solenidion $\varphi 1$ thick, clavate, $\omega 1$ digitiform; other solenidia weakly clavate. Leg II (Fig. 2B). Setal formula: 1-3-1-4-6(1). Tarsus with thickened basally claws and flipper-like empodium. Solenidion $\omega 6$ (6) weakly clavate, solenidion $\varphi$ absent. All setae barbed; seta $t c$ ' of tarsus spiniform, blunt-tipped; setae $d, l$, $v$ "' of femur and $l$ ' of genu blunt-tipped; other leg setae pointed. Leg III (Fig. 3A). Femur divided into basi- and telofemur. Setal formula: 1-2-1-4-6. Claws and empodium of same shape as on tarsus II. All setae barbed; setae $v$ ' of trochanter, $d, v^{\prime}$ of femur and $l$ ' of genu blunt-tipped, other leg setae pointed; solenidion $\varphi$ absent. Leg IV (Fig 3B). Femur divided into basi- and telofemur. Setal formula: 1-2-0-4-6. Claws simple, empodium round, stalked. All setae barbed; setae $v$ ' of trochanter, $d$ of femur, $v$ " of tibia and $p l$ " of tarsus blunt-tipped, other leg setae pointed; solenidion $\varphi$ absent.

Male unknown. 


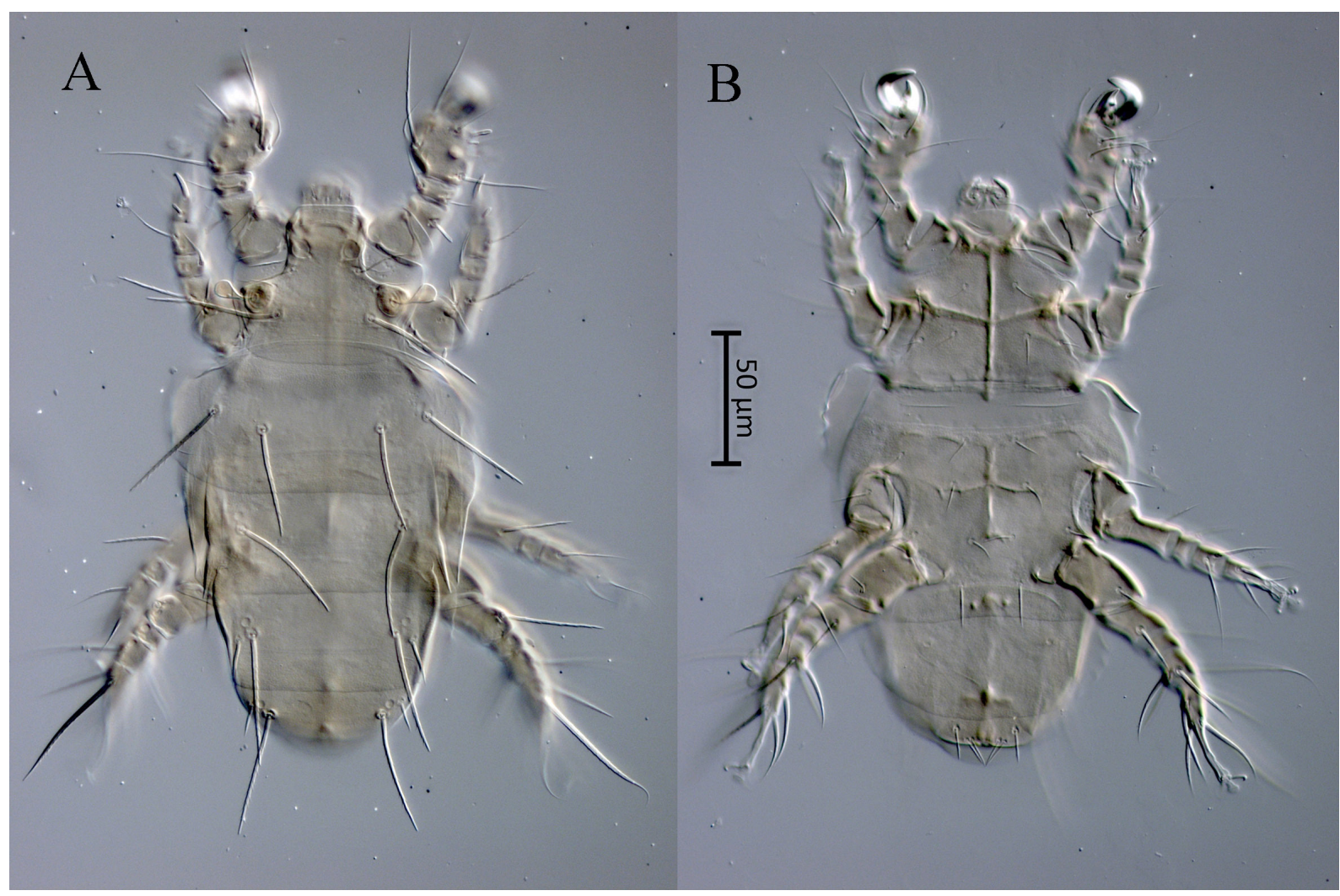

Fig. 4. DIC micrographs of Spatulaphorus dignus sp.n., female: A—general view dorsally, B—general view ventrally

Type material. Female holotype, slide ZISP T-Pygm-007, French Guiana, St. Georges, 3. II.2018, O. Montreuil leg., on beetle Oxysternon durantoni; paratypes: 13 females, same data.

Type deposition. The holotype and four paratypes are deposited in the collection of the Zoological Institute of the Russian Academy of Sciences (RAS), Saint Petersburg, Russia; other paratypes are deposited in the collection of the Tyumen State University Museum of Zoology, Tyumen, Russia.

Differential diagnosis. The new species is most similar to $S$. brasiliensis Khaustov and Frolov, 2017, described from Brazil (Khaustov and Frolov 2017), in: the similar lengths and shapes of dorsal and ventral setae; absence of foliate setae on tarsi $\mathrm{I}-\mathrm{IV}$; the characteristic position of setae $p s 3$ distinctly anteriad ps 1-2; absence of spiniform setae on tarsus III. The new species differs from $S$. brasiliensis in: barbed setae $e$ (vs. smooth in S. brasiliensis), having spiniform seta $t c$ ' on tarsus II (vs. not modified in S. brasiliensis), absence of big puncta on idiosomal tergites (vs. idiosomal tergites with big puncta in S. brasiliensis), much longer and thicker seta $p l$ " on tarsus IV.

Etymology. The name of the new species is derived from Latin dignus meaning dignified.

\section{Spatulaphorus porosus sp. n.}

(Figs. 7-11)

Description. Female (Figs. 7-11). Body well sclerotized. Length of idiosoma 235 (215-245), width 125 (110-130).

Gnathosoma. As in S. dignus sp.n., except shorter, weakly blunt-tipped setae $m$ 3(3-5). Length of gnathosoma 20 (19-22), width 21 (20-23). Lengths of setae: cha 5 (5-6), pp 2 (2), dFe 3 (3), dGe 7 (6-7).

Idiosomal dorsum (Figs. 7A, 10A, 11A, C, E) in general very similar to $S$. dignus sp.n. All dorsal shields with big pore-like puncta (Figs. 11A, C, E). All dorsal idiosomal setae blunt-tipped; setae $v 2$ smooth, other dorsal setae barbed; setae $h 2$ with one or two barbs. Lengths of dorsal setae: $v 130$ (28-32), v2 12 (12-14), sc2 44 (47-60), c1 48 (47-52), c2 51 (51-57), d 54 (51-59), e 21 (21-23), f 53 (5360), h1 50 (50-59), h2 12 (12-13). Distances between setae: $v 1-v 122$ (21-23), v2-v2 34 (31-37), $s c 2-s c 237$ (34-40), c1-c1 39 (38-44), c1-c2 24 (22-24), $d-d 56$ (52-62), e-f8 (8-9), f-f53 (49-58), h1-h1 42 (38-45), h1-h2 10 (10-11).

Idiosomal venter (Figs. 7B, 10B, 11B, D, F) in general very similar to $S$. dignus sp.n. All ventral plates with numerous tiny puncta, aggenital plate 


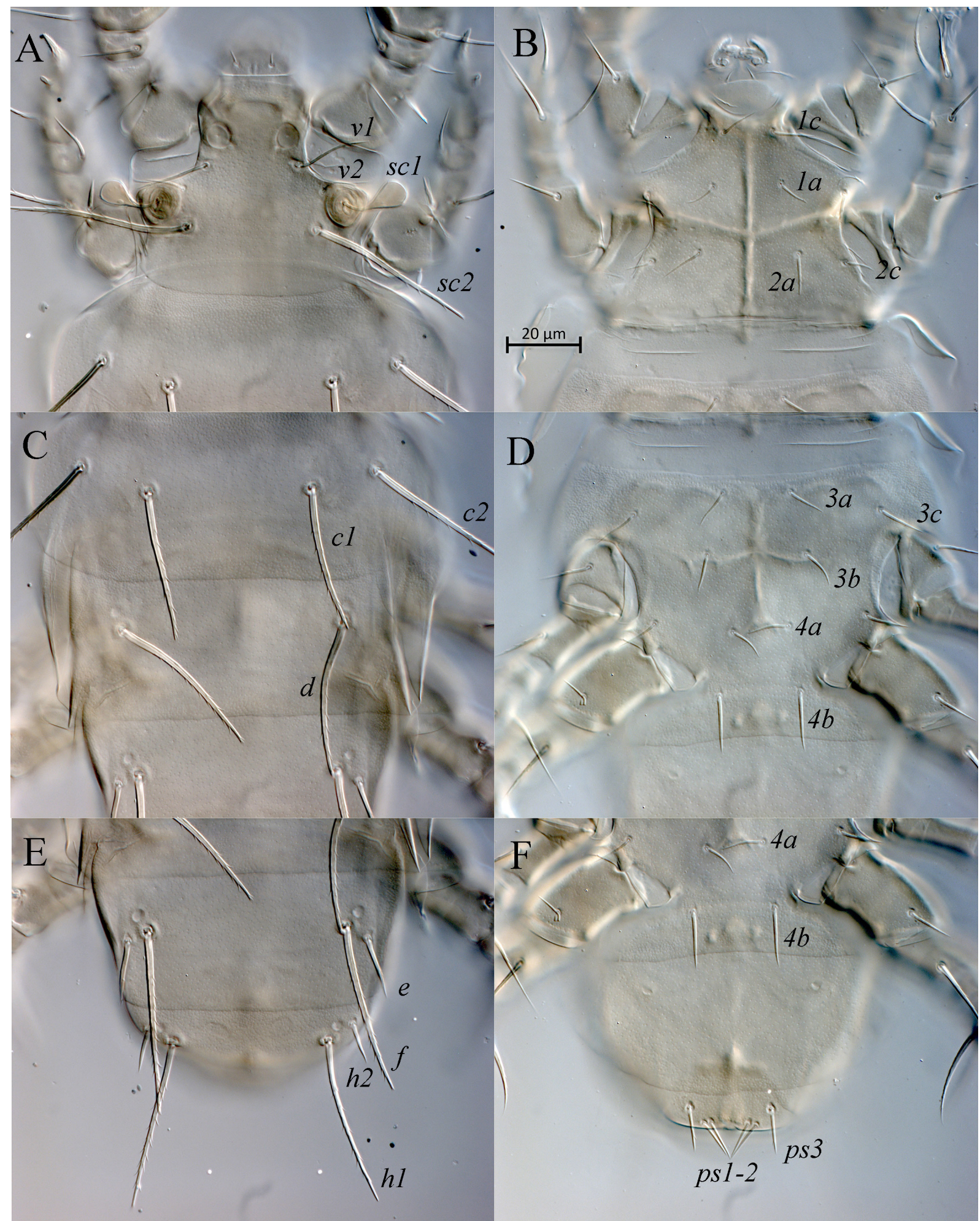

Fig. 5. DIC micrographs of Spatulaphorus dignus sp.n., female: A—prosoma, dorsal aspect, B-prosoma, ventral aspect, C—metapodosoma, dorsal aspect, D—metapodosoma, ventral aspect, E—opisthosoma, dorsal aspect, Fopisthosoma, ventral aspect.

and anterolateral parts of coxal fields I and II with some big puncta (Figs. 11B, D, F). Lengths of ventral setae: $1 a 11$ (11-12), $1 b 20$ (19-21), $1 c 12$ (12-14), $2 a 12$ (12-14), 2c 11 (10-12), 3a 12
(12-16), $3 b 12$ (12-13), 3c 16 (15-16), 4a 12 (12-13), $4 b 19$ (19-22), 4c 14 (14-16), ps1 14 (13-14), ps2 14 (14-16), ps3 17 (17-19). 


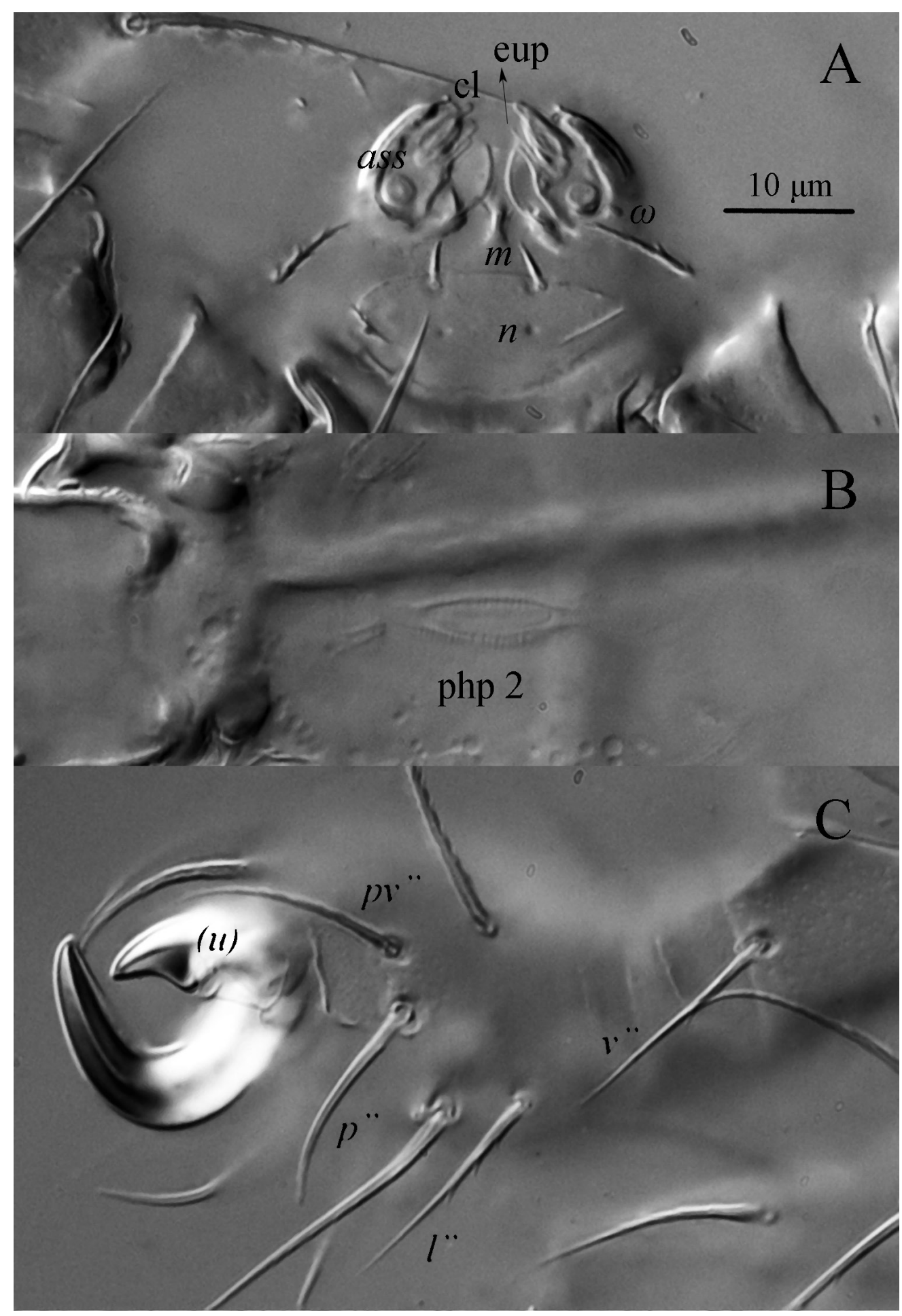

Fig. 6. DIC micrographs of Spatulaphorus dignus sp.n., female: A—gnathosoma, ventral aspect, B — pharyngeal pump 2, C—-tibiotarsus I, ventral aspect; cl—tibial claw, eup — eupathid-like seta.

Legs (Figs. 8, 9). Leg setation as in S. dignus sp.n. Leg I (Fig. 8A) as in S. dignus sp.n., except pointed setae $v$ " of femur and $l$ ' of genu. Lengths of solenidia $\omega 19$ (9), $\omega 25$ (5-6), $\varphi 18$ (8), $\varphi 25$ (5-6). Leg II (Fig. 8B) as in S. dignus sp.n., except pointed seta $l$ ' on genu. Solenidion $\omega 7$ (7) weakly clavate. Legs III (Fig. 9A) and IV (Fig. 9B) as in S. dignus sp.n.
Male unknown.

Type material. Female holotype, slide ZISP T-Pygm-008, French Guiana, St. Georges, 3. II.2018, O. Montreuil leg., on beetle Coprophanaeus jasius; paratypes: 14 females, same data.

Type deposition. The holotype and four paratypes are deposited in the collection of the Zoo- 


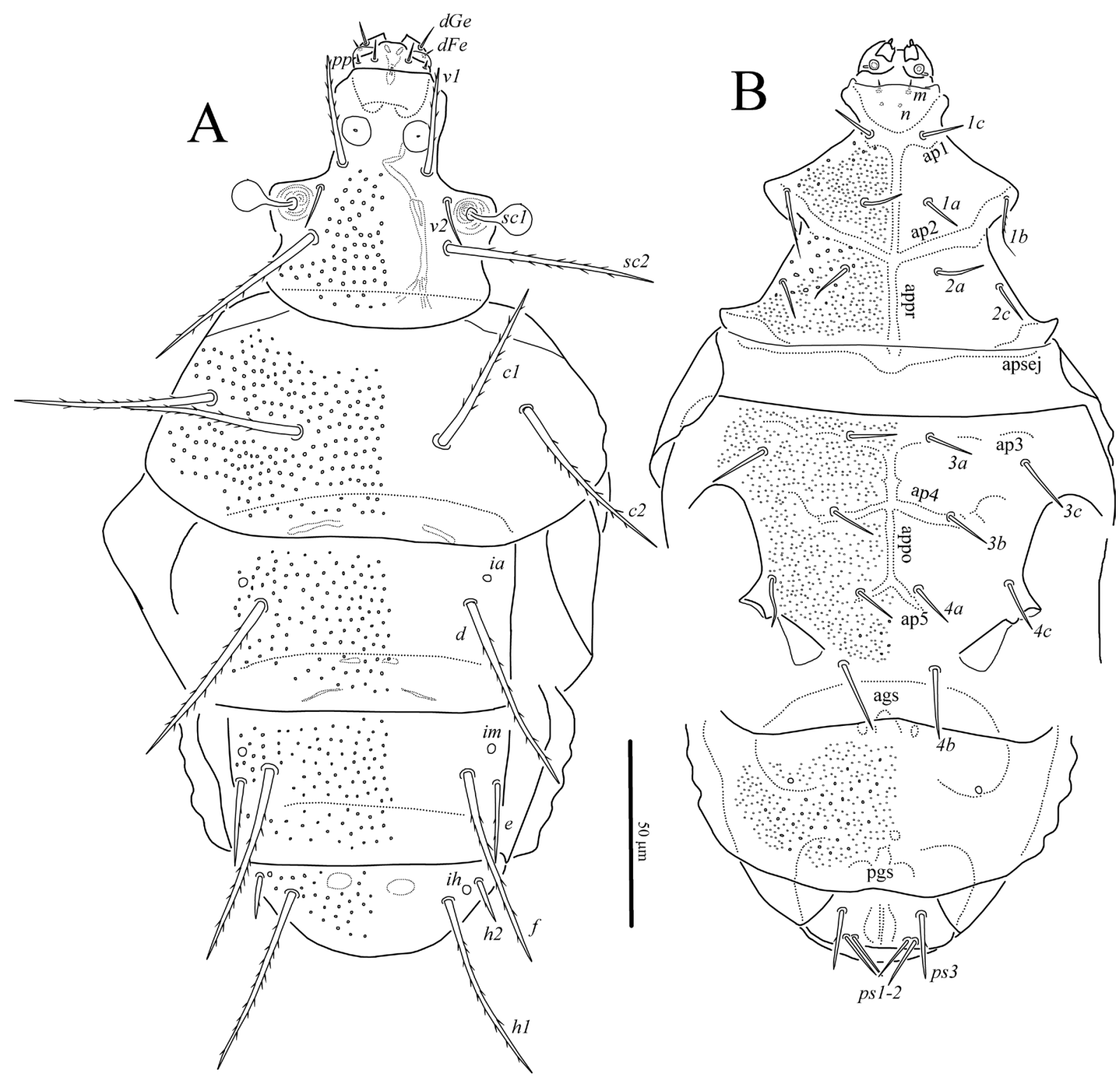

Fig. 7. Spatulaphorus porosus sp.n., female: A—dorsum of body, B-venter of body. Legs omitted.

logical Institute of RAS, Saint Petersburg, Russia; other paratypes are deposited in the collection of the Tyumen State University Museum of Zoology, Tyumen, Russia.

Differential diagnosis. The new species is very similar to $S$. dignus sp.n. The new species differs from $S$. dignus sp.n. in having big pore-like puncta on dorsal idiosomal tergites, aggenital plate, and coxal fields I and II (vs. big puncta absent in S. dig$n u s)$ and in having a clearly longer setae $1 b$ (19-21) (vs. 12-14 in S. dignus).

Etymology. The name of the new species is derived from Greek $\pi$ ó $\rho$ s meaning pore and refers to big pore-like puncta on idiosomal sclerites.

\section{Spatulaphorus brasiliensis Khaustov and Frolov, 2017}

Spatulaphorus brasiliensis Khaustov and Frolov, 2017: 513.

This species was described from Brazil (Khaustov and Frolov 2017) from the scarab beetle $D i$ chotomius podalirius. This is the first record of $S$. brasiliensis from French Guiana. Dichotomius borreus is a new phoretic host for S. brasiliensis.

Material examined. Seventeen females, French Guiana, St. Georges, 3.II.2018, O. Montreuil leg., on beetle Dichotomius borreus. 


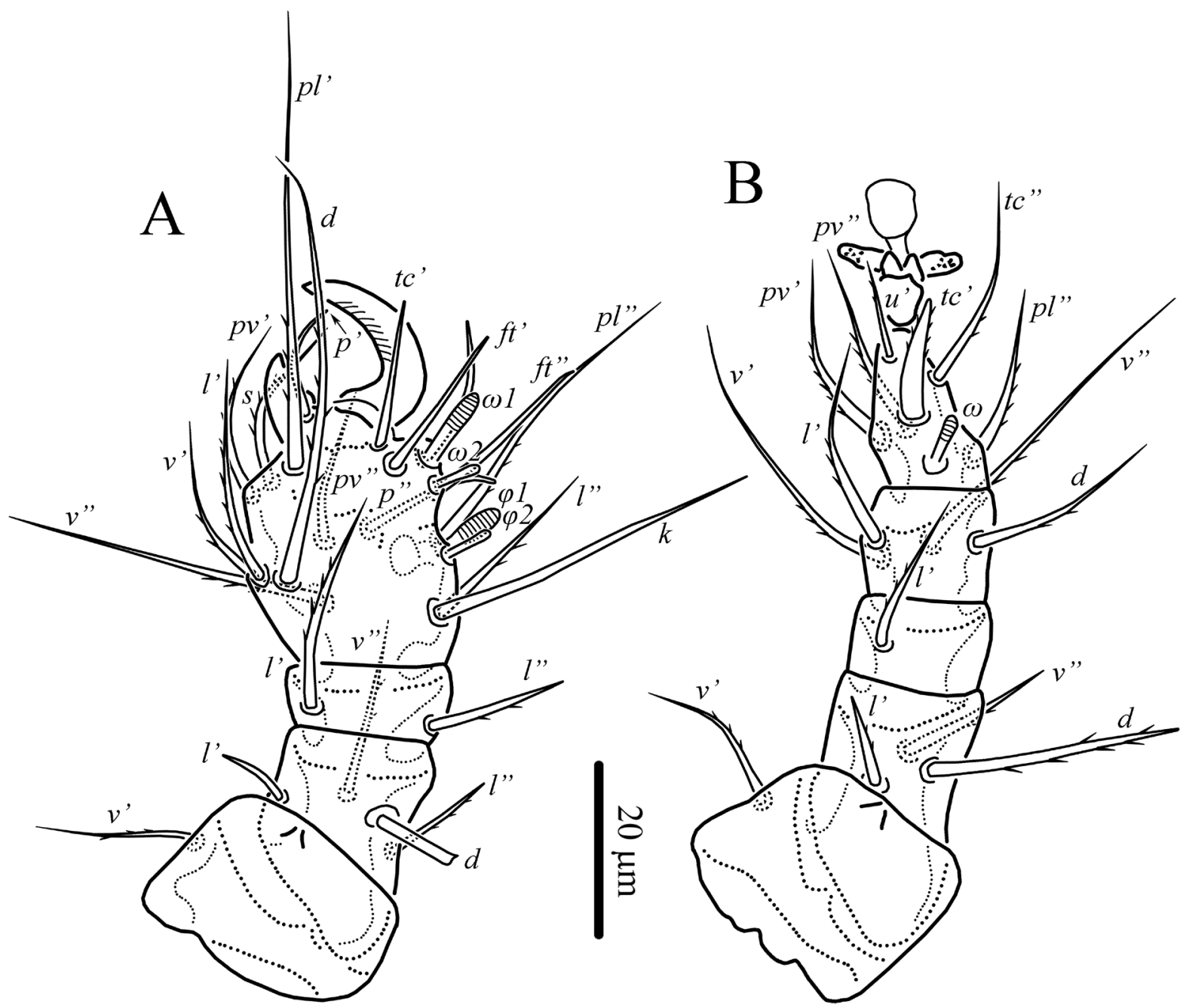

Fig. 8. Spatulaphorus porosus sp.n., female: A—right leg I, dorsal aspect, B—right leg II, dorsal aspect.

\section{KEY TO WORLD SPECIES OF SPATULAPHORUS} (based on Khaustov and Frolov 2018)

1. Genu I with two setae .2

— Genu I with one seta....S. copridis Khaustov, 2007 (Crimea, Iran)

2. Tarsi II and III each with spiniform setae $p l$ " and $t c^{\prime}$.

— Tarsi II and III without spiniform setae, or only $p l$ "' or $t c$ ' spiniform

3. Setae $s c 2$ foliate ... S. vladimiri Khaustov, 2005 (Ukraine, Crimea, Iran)

- Setae $s c 2$ not modified, setiform 4

4. Setae $c 2$ foliate, blunt-tipped

S. venustus Khaustov and Trach, 2012

(Ukraine)

- Setae $c 2$ not modified, pointed.....

S. altaicus Khaustov and Trach, 2018

(Russia: Altai)

5. At least setae $(p v)$ on tarsus II foliate distally ... 6
— Setae $(p v)$ on tarsus II not foliate distally .... 10

6. Tibiotarsus I with large, hook-like claw and a distinct counterpart opposite to the claw base ....7 - Tibiotarsus I with a small, almost straight claw, and no counterpart..... S. foliatus Dastych and Rack, 1993 (Botswana)

7. Tarsi II and III with setae $t c$ 'not modified ......8 - Tarsi II and III with setae $t c$ 'spiniform S. langi Dastych and Rack, 1993

(Vietnam)

8. Setae $p s_{3}$ subequal to or shorter than $p s 1,2 \ldots .9$ - Setae $p s 3$ distinctly longer than $p s 1,2$.

S. luriei Dastych, Rack and Camerik, 1997 (South Africa)

9. Setae $(p v)$ on tarsus III foliate, setae $p s 1,2$ distinctly barbed

.... S. enoplotruporum Khaustov and Frolov, 2018 (Thailand)

- Setae ( $p v)$ on tarsus III not foliate, setae $p s 1,2$ smooth...... S. camerikae Dastych and Rack, 1993 (Botswana) 


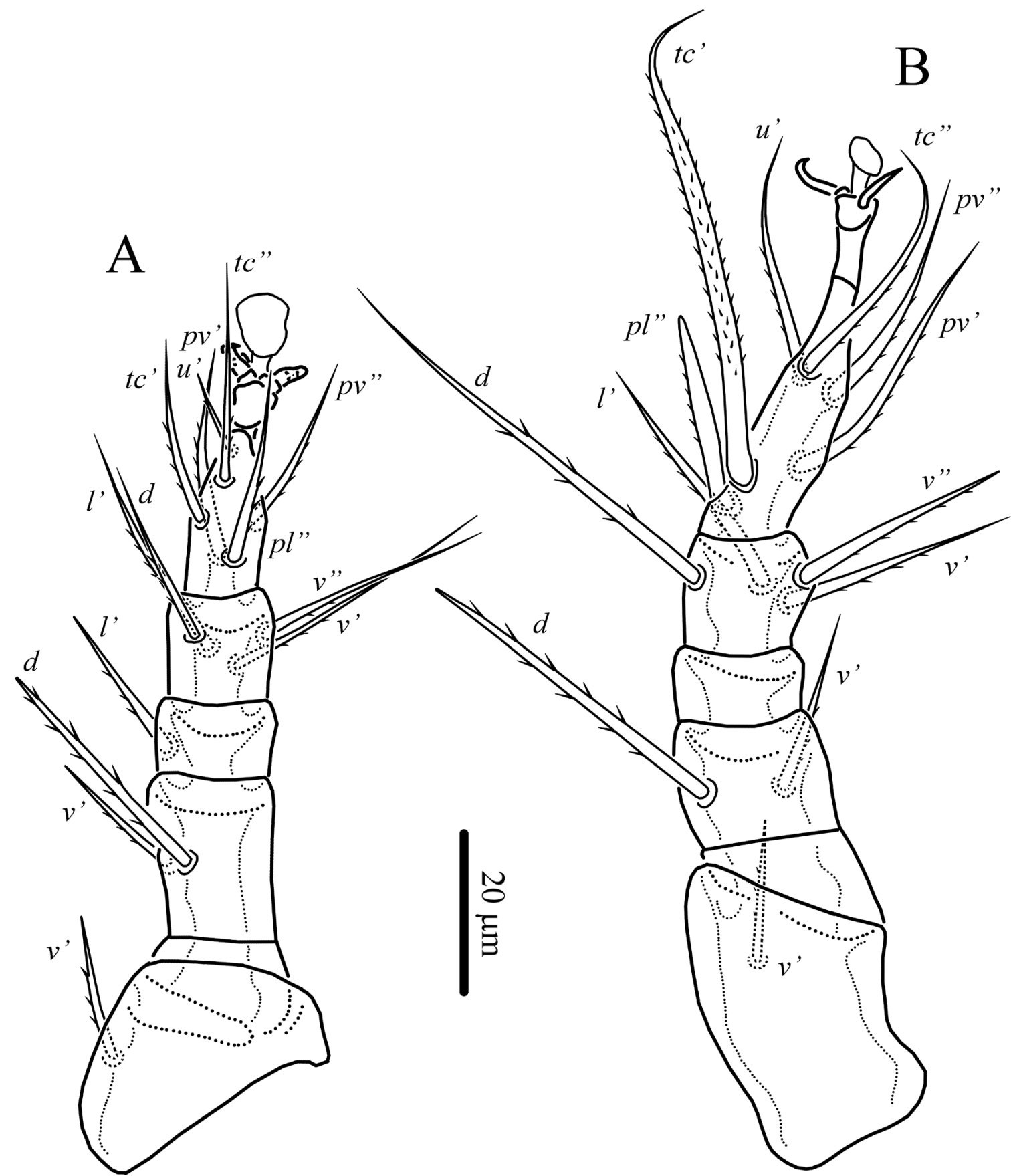

Fig. 9. Spatulaphorus porosus sp.n., female: A—right leg III, dorsal aspect, B—right leg IV, dorsal aspect.

10. Tarsi II and III with setae $p l$ " not modified .....11

— Tarsi II and III with setae $p l$ " spiniform

..S. gorganica Rahiminejad and Hajiqanbar, 2011 (Iran, Crimea)

11. Apodemes 4 long, exceeding beyond setae $3 b . .12$

- Apodemes 4 vestigial

S. geotruporum Khaustov, 2005

(Ukraine)

12. Setae $p s 3$ situated on the same transverse level with $p s 1-2$

— Setae $p s 3$ situated distinctly anteriad $p s 1-2 \ldots .14$
13. Setae $e$ more than two times longer than $h 2$, setae ps3 and ps1-2 subequal.. S. geotrupi (Mahunka, 1970) (Hungary)

- Setae $e$ and $h_{2}$ subequal; setae ps 3 more than two times longer than $p s 1-2$

......... S. gymnopleuri Sobhi and Hajiqanbar, 2017 (Iran)

14. Seta $t c$ ' on tarsus II spiniform 15

- Seta $t c$ ' on tarsus II not modified

S. brasiliensis Khaustov and Frolov, 2017

(Brazil) 


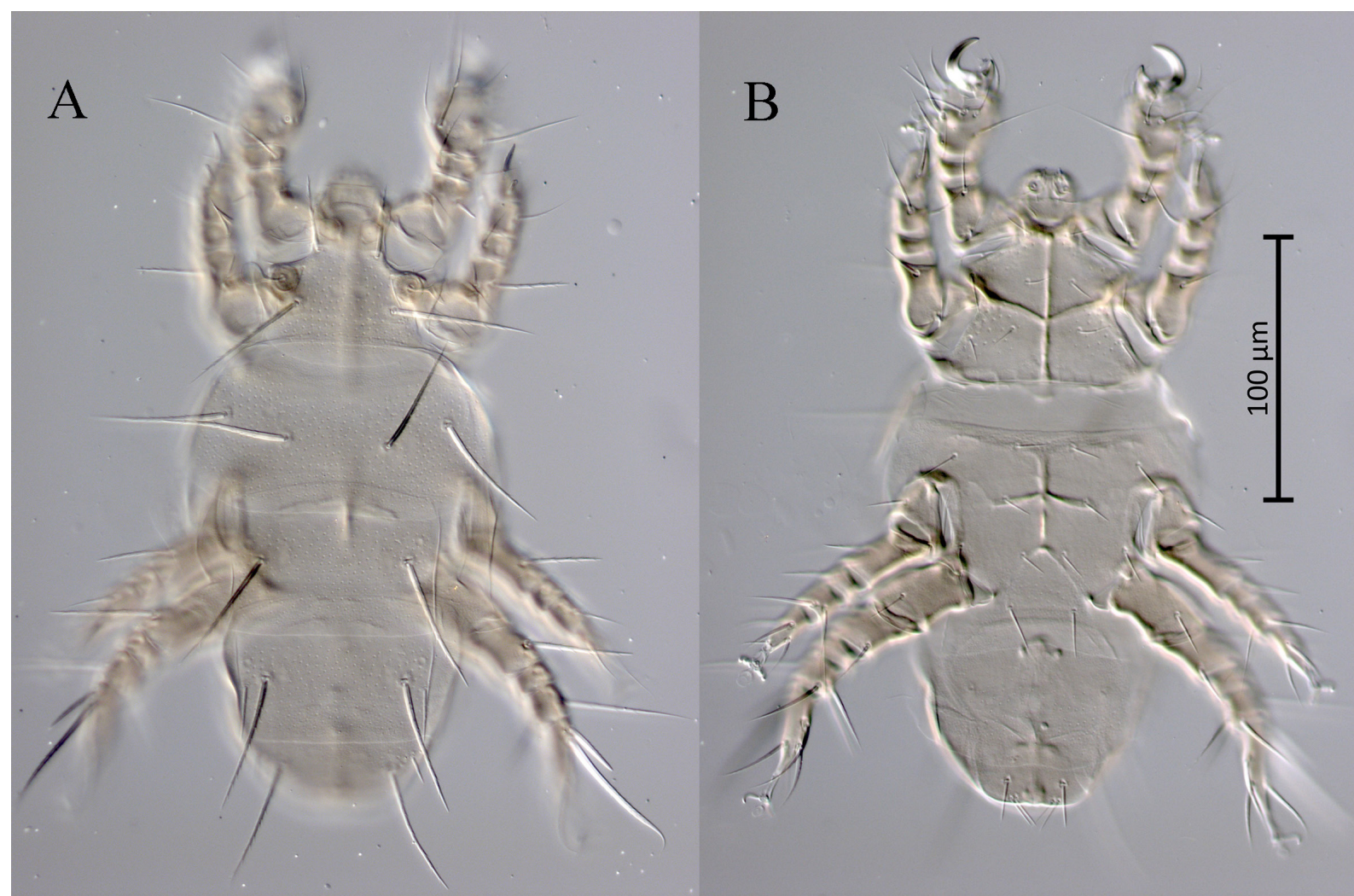

Fig. 10. DIC micrographs of Spatulaphorus porosus sp.n., female: A—general view dorsally, B—general view ventrally

15. Idiosomal tergites with big puncta (Fig. 7A).. S. porosus sp.n.

- Idiosomal tergites only with tiny puncta (Fig. 1A). S. dignus sp.n.

\section{ACKNOWLEDGEMENTS}

We are thankful to Olivier Montreuil (National Museum of Natural History, Paris, France) who provided the host beetles for examination. This research was supported by the cooperative agreement No. FEWZ-2021-0004, funded by the Russian Ministry of Science and Higher Education. The study of the junior author was performed in the framework of the Russian State Research Project No. AAAA-A19-119020690101-6.

\section{REFERENCES}

Dastych, H. and Rack, G. 1993. Spatulaphorus gen.n. and three new species of pygmephorid mites associated with scarab beetles in Botswana and Vietnam (Acari: Heterostigmata). Mitteilungen Hamburgisches Zoologisches Museum und Institut, 90: 265-84.

Dastych, H., Rack, G., and Camerik, A. M. 1997. A new species of the genus Spatulaphorus Rack (Acari: Heterostigmata, Pygmephoridae) associated with scarab beetles in South Africa. Mitteilungen aus dem Hamburgischen Zoologischen Museum und Institut, 94: 145-151.

Grandjean, F. 1944. Observations sur les Acariens de la famille des Stigmaeidae. Archives des Sciences Physiques et Naturelles, 26: 103-131.

Grandjean, F. 1947. L'origine pileuse des mors et la chaetotaxie de la mandibule chez les Acariens actinochitineux. Comptes Rendus des Séances de l'Academie des Sciences, 224: 1251-1254.

Katlav, A., Hajiqanbar, H. and Talebi, A.A. 2015a. Pseudopygmephorellus mazandaranicus sp.n. (Acari: Heterostigmata: Pygmephoridae), phoretic on scarabaeid dung beetles (Coleoptera: Scarabaeidae) from Iran. Zootaxa, 3919: 100-110. DOI: 10.11646/zootaxa.3919.1.5

Katlav, A., Hajiqanbar, H. and Talebi, A.A. 2015b. A contribution to the knowledge of heterostigmatic mites (Acari: Prostigmata) in western Mazandaran Province, Northern Iran. Acarologia, 55: 311-320. DOI: 10.1051/acarologia/20152175

Khaustov, A.A. 2004. Mites of the family Neopygmephoridae Cross, 1965 stat.n. and their position in Heterostigmata. In: Y.S. Balashov (Ed.). VIII Russian Acarological Conference, St-Petersburg. Zoological Institute of RAS, St.-Petersburg, 137 pp. [In Russian]

Khaustov, A.A. 2005. Three new species of mite family Pygmephoridae (Acari: Heterostigmata) associ- 


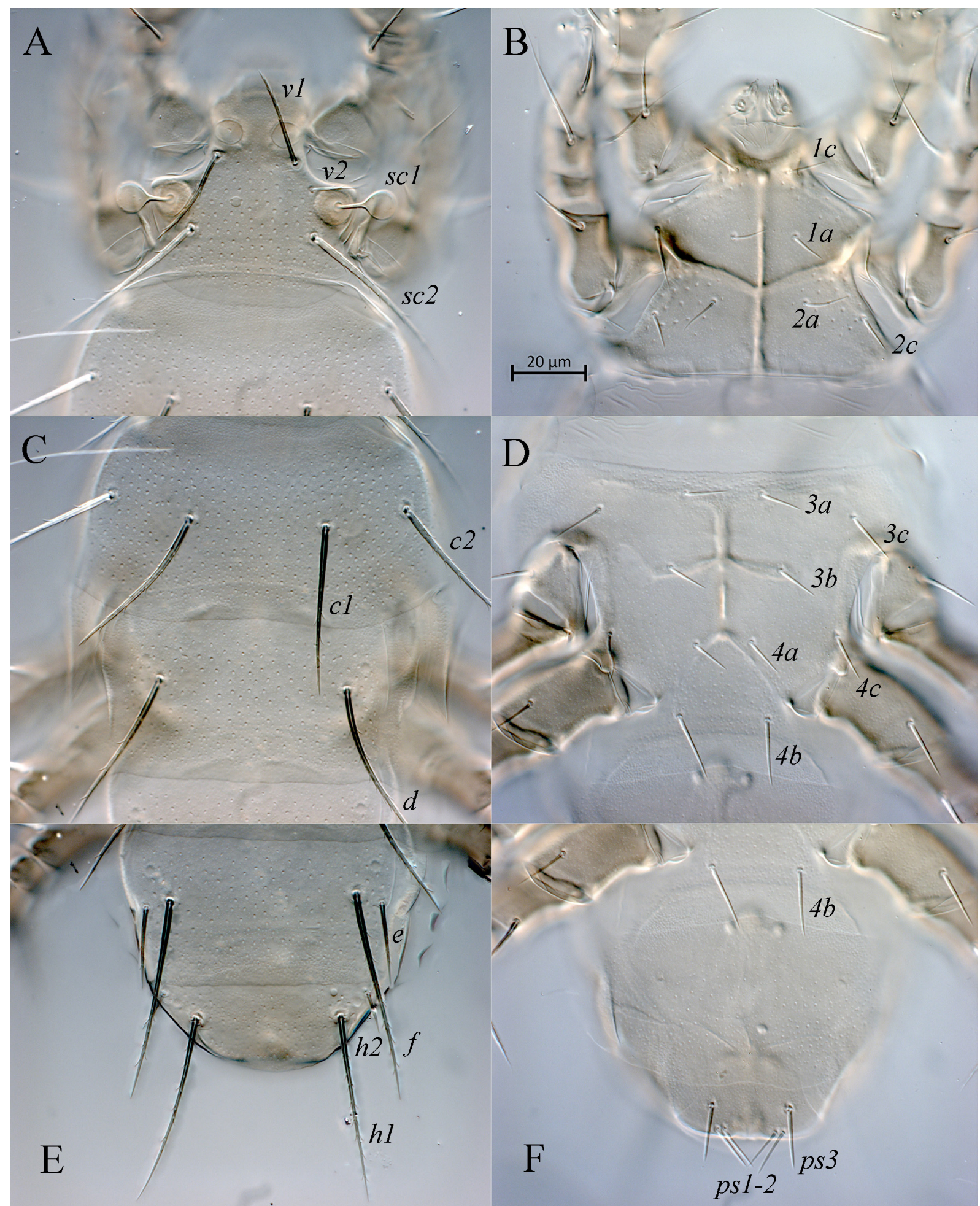

Fig. 11. DIC micrographs of Spatulaphorus porosus sp.n., female: A-prosoma, dorsal aspect, B-prosoma, ventral aspect, C—metapodosoma, dorsal aspect, D—metapodosoma, ventral aspect, E-opisthosoma, dorsal aspect, Fopisthosoma, ventral aspect.

ated with scarab beetles (Coleoptera: Scarabaeidae) from Ukraine. Acarina, 13: 35-42.

Khaustov, A.A. 2007a. A new species of the genus Spatulaphorus (Acari: Heterostigmata: Pygmephoridae) associated with Copris lunaris (Coleoptera: Scarabaeidae) from Crimea. Acarina, 15: 155-157.
Khaustov, A.A. 2007b. A new species of the genus Pygmephorellus (Acari: Heterostigmata: Pygmephoridae) associated with Geotrupes stercorarius (Coleoptera: Geotrupidae) from Crimea. Acarina, 15: 287-289. 
Khaustov, A.A. 2008. Mites of the family Scutacaridae of Eastern Palaearctic. Akademperiodyka, Kyiv, $291 \mathrm{pp}$.

Khaustov, A.A. and Frolov, A.V. 2017. New species of heterostigmatic mites (Acari: Heterostigmata: Athyreacaridae, Dolichocybidae, Pygmephoridae) associated with scarab beetles (Coleoptera: Geotrupidae, Scarabaeidae) from Brazil. Zootaxa, 4294(5): 501-521. DOI: 10.11646/zootaxa.4294.5.1

Khaustov, A.A. and Frolov, A.V. 2018. New taxa of pygmephoroid mites (Acari: Pygmephoroidea: Pygmephoridae, Neopygmephoridae) phoretic on Enoplotrupes sharpi (Coleoptera: Geotrupidae) from Thailand. Zootaxa, 4442(2): 277-292. DOI: 10.11646/zootaxa.4442.2.5

Khaustov, A.A. and Frolov, A. V. 2019. Two new species of Pseudopygmephorellus (Acari: Heterostigmata: Pygmephoridae) phoretic on beetles of the genus Rhyparus (Coleoptera: Scarabaeidae: Aphodiinae) from Papua New Guinea and Indonesia. Systematic and Applied Acarology, 24(8): 15411554. DOI: $10.11158 / \mathrm{saa} .24 .8 .14$

Khaustov, A.A. and Trach, V.A. 2012. A new species and new records of mites of the genus Spatulaphorus Rack (Acari: Heterostigmata: Pygmephoridae) from Ukraine. International Journal of Acarology, 38: $480-485$.
Khaustov, A.A. and Trach, V.A. 2018. New species of Spatulaphorus (Acari: Heterostigmata: Pygmephoridae) associated with Geotrupes baicalicus (Coleoptera: Geotrupidae) from Altai Republic, Russia. Systematic and Applied Acarology, 23: 123-131. DOI: 10.11158/saa.23.1.10

Lindquist, E.E. 1986. The world genera of Tarsonemidae (Acari: Heterostigmata): a morphological, phylogenetic, and systematic revision, with a reclassification of family-group taxa in the Heterostigmata. Memoirs of Entomological Society of Canada, 118: 1-517.

Rahiminejad, V., Hajiqanbar, H. and Fathipour, Y. 2011. A new species of the genus Spatulaphorus (Acari: Heterostigmatina: Pygmephoridae) phoretic on Geotrupes spiniger (Coleoptera: Geotrupidae) from Iran. Annales Zoologici, 61: 547-551. DOI: 10.3161/000345411X603391

Sobhi, M., Hajiqanbar, H. and Mortazavi, A. 2017. A new species of the genus Spatulaphorus (Acari: Heterostigmata: Pygmephoridae) associated with Gymnopleurus flagellatus (Coleoptera: Scarabaeidae) from Iran. Systematic and Applied Acarology, 22: 217-223. DOI: 10.11158/saa.22.2.6

Stathakis, T.I., Kapaxidi, E.V. and Papadoulis, G.Th. 2016. The genus Eustigmaeus Berlese (Acari: Stigmaeidae) from Greece. Zootaxa, 4191(1): 1-102. 